\title{
A Phl p 7-specific lgG4 antibody inhibits allergic patients IgE cross-reactivity to allergens from the EF-hand family: importance of affinity and degree of cross-reactivity
}

\author{
Elisabeth Gadermaier ${ }^{1 *}$, Louise K James ${ }^{2}$, Mohamed H Shamji ${ }^{3}$, Katrina Blatt ${ }^{4}$, Tetiana Garmatiuk², Rebecca Beavil , \\ Sabine Flicker ${ }^{1}$, Peter Valent ${ }^{4}$, Stephen R Durham³ ${ }^{3}$, Hannah J Gould ${ }^{2}$, Rudolf Valenta ${ }^{1}$
}

From 5th International Symposium on Molecular Allergology (ISMA 2013)

Vienna, Austria. 6-7 December 2013

\section{Background}

The calcium-binding 2EF-hand protein Phl p 7 from timothy grass pollen is a cross-reactive pollen panallergen that can induce severe clinical symptoms in allergic patients. Recently, a human Phl p 7-specific IgG4 antibody which inhibited IgE binding to Phl p 7 was isolated and characterized.

\section{Objective}

To study epitope-specificity and cross-reactivity of the $\mathrm{Phl}$ p 7-specific IgG4 with homologous pollen allergens as well as the extent of cross-protection.

\section{Methods and results}

Sequence comparison showed a comparable sequence identity of approximately $70 \%$ between the $2 \mathrm{EF}$-hand pollen allergens (Timothy grass: Phl p 7; Alder: Aln g 4; Birch: Bet v 4; Turnip rape: Bra r 1; Lamb's quarter: Che a 3; Olive: Ole e 3) and a lower sequence identity of $44 \%$ with the 4EF-hand allergen from olive pollen (Ole e 8). While patients' IgE showed extensive cross-reactivity with the EF-hand allergens, the Phl p 7-specific IgG4 showed limited cross-reactivity. Best cross-reactivity was observed with Ole e 3 whereas the other EF-hand allergens were less recognized by the Phl p 7-specific IgG4 in dot blot experiments. Calcium-depletion experiments showed that the binding of the Phl p 7-specific IgG4 depended on the presence of calcium. Using peptide- specific antisera the binding site of the IgG4 was located in the $\mathrm{C}$-terminal portion of the allergen which contains the second calcium-binding EF-hand motif. Biacore experiments revealed interesting differences regarding the affinity of the Phl p 7-specific IgG4. Phl p 7 and Ole e 3 were recognized with the highest affinity (KD's: Phl $\mathrm{p}$ 7: 2,11x10-9M; Ole e 3:6,18x10-9M) whereas the affinities to the other cross-reactive allergens was much lower (Bet v 4: 6,26x10-6M; Bra r 1: 6,57x10-6M; Aln g 4: 7,93x10-6M). The cross-inhibition of patients' IgE reactivity to the EF-hand allergens and the inhibition of allergen-induced basophil activation obtained with the $\mathrm{Phl} \mathrm{p}$ 7-specific IgG4 followed its intensity of cross-reactivity and affinity with the homologous allergens.

\section{Conclusion}

Our results demonstrate that the Phl p 7-specific IgG4 antibody shows cross-inhibition of allergic patients IgE reactivity and basophil activation induced by homologous allergens according to cross-reactivity and affinity. Funded by grants P23318-B11 and in parts by grants F4607 and F4605 of the Austrian Science Fund (FWF).

\section{Authors' details}

'Medical University of Vienna, Center for Pathophysiology, Infectiology and Immunology, Vienna, Austria. ${ }^{2}$ King's College London, Randall Division of Cell and Molecular Biophysics, London, UK. ${ }^{3}$ Imperial College London Allergy and Clin Immunol, National Heart/Lung Inst, London, UK. ${ }^{4}$ Medical University of Vienna, Vienna General Hospital, Department of Internal Medicine I, Vienna, Austria.

'Medical University of Vienna, Center for Pathophysiology, Infectiology and Immunology, Vienna, Austria

Full list of author information is available at the end of the article 

inhibits allergic patients lgE cross-reactivity to allergens from the EFhand family: importance of affinity and degree of cross-reactivity. Clinical and Translational Allergy 2014 4(Suppl 2):08.

Submit your next manuscript to BioMed Central and take full advantage of:

- Convenient online submission

- Thorough peer review

- No space constraints or color figure charges

- Immediate publication on acceptance

- Inclusion in PubMed, CAS, Scopus and Google Scholar

- Research which is freely available for redistribution

Submit your manuscript at www.biomedcentral.com/submit
() Biomed Central 